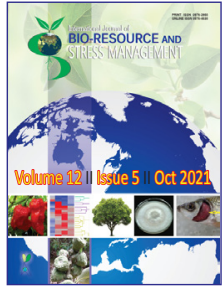

\title{
Aromatic Rice with Multiple Disease Resistance Developed through Anther Culture
}

\author{
Pawankumar Kharate, Pratik Pusadkar, Nirmala Bharti Patel, Shrinkhla Maurya and Zenu Jha*
}

Dept. of Plant Molecular Biology and Biotechnology, Indira Gandhi Krishi Vishwavidyalaya, Raipur, CG (492 012), India

\begin{abstract}
$?$
Open Access

Corresponding Author

Zenu Jha

e-mail: drzenujha@gmail.com

Citation: Kharate et al., 2021. Aromatic Rice with Multiple Disease Resistance Developed through Anther Culture. International Journal of Bio-resource and Stress Management 2021, 12(5), 431-440. HTTPS://DOI.ORG/10.23910/1.2021.2370.

Copyright: ㄷ 2021 Kharate et al. This is an open access article that permits unrestricted use, distribution and reproduction in any medium after the author(s) and source are credited.

Data Availability Statement: Legal restrictions are imposed on the public sharing of raw data. However, authors have full right to transfer or share the data in raw form upon request subject to either meeting the conditions of the original consents and the original research study. Further, access of data needs to meet whether the user complies with the ethical and legal obligations as data controllers to allow for secondary use of the data outside of the original study.
\end{abstract}

Conflict of interests: The authors have declared that no conflict of interest exists.

\section{Article History}

RECEIVED on $17^{\text {th }}$ May 2021 RECEIVED in revised form on $30^{\text {th }}$ September 2021 ACCEPTED in final form on $15^{\text {th }}$ October 2021

\begin{abstract}
The experiments were conducted during kharif (June to September) 2018 and 2019 to screen 7 aromatic rice double haploid (DH) lines developed against Bacterial Leaf Bligh (BLB) and blast disease. Three genes Xa21, xa13, xa5 for BLB resistance and two genes Pi1, Pi2 for blast resistance was introgressed into a local aromatic rice variety Dubraj from Chhattisgarh State of India. Dubraj is extremely popular aromatic short medium grain variety in Chhattisgarh and Madhya Pradesh region and hence used in this study. RPBIO-226 and PR122 rice variety is used as donor for BLB and blast resistance respectively. $7 \mathrm{DH}$ lines (L-1 to L-7) were developed from the crosses (Dubraj X RPBIO-226 X PR122) in the year 2017. Phenotypic evaluation for BLB diseases resistance has shown that L-1, L- 6 and L-7 (score 1) has a similar resistance as the control check RPBIO-226(score-1) and 3 lines with moderate resistance (L-3 score 2) (L-4 score 3 ) (L-5 score 3). For blast disease, three lines ( $L-4, \mathrm{~L}-6$ and $\mathrm{L}-7$ ) were identified as resistance with the disease score of 1 , whereas three were grouped under the section moderately resistant (L-1, L-3 and L- 5) with a disease score of 3. Sensory test $(1.7 \% \mathrm{KOH})$ was conducted for the estimation of presence / absence of aroma. Moderately strong aroma was present in four lines (L-1, L-3, L- 6 and L-7). On the basis of yield and presence of aroma in grain, $\mathrm{L}-3$ has been selected with moderately resistant to BLB and blast for further advancement and subsequently evaluated under State Initial Evaluation Trial (SIET) during kharif 2020. Within 3 years of development of DH line, L-3 is under varietal developmental trail, which itself indicate the efficacy of anther culture in fixing homozygosity and speedy development of desired variety within short period of time.
\end{abstract}

Keywords: Bacterial leaf blight, blast, double haploid, molecular markers, rice, sensory test

\section{Introduction}

Due to ineffectiveness of chemicals and antibiotics in controlling the disease, development of disease resistant cultivars is the best way for management of this destructive disease. The deployment of rice cultivars that have multiple BLB resistance genes is expected to lead to more durable resistance (Kadu et al., 2018). In future there is need of improved high yielding rice cultivar having multiple disease resistance because rice crop is considered a major food crop for billions of people that rely on rice as their staple food (Chukwu et al., 2019). Hybridization and selection for yield and quality traits have led to the development of new rice varieties, resulting in loss of genes responsible for biotic and abiotic stresses. Among the biotic stresses, the major diseases of rice are 
bacterial leaf blight (BLB) and blast that caused by pathogen Xanthomonas oryzae pv. oryzae and Magnaporthe grisea Barr respectively (Ou, 1985; Mew et al., 1992). Infection of BLB at a maximum tillering stage results to $20-40 \%$ yield reduction Yasmin et al., 2017) while due to the leaf blast yield loss can be as high as 50\% (Babujee and Gnanamanickam, 2000). Anther culture technology have long been recognized as a method of advancing heterozygous population to homozygosity, but also allow the quick screening between genotypes within one generation (Chen et al., 2002). Double haploid technique through anther culture can accelerate the breeding cycle and allow better discrimination between genotype within one generation (Maria et al., 2006). Several rice DH varieties with superior grain quality characteristics, resistant to diseases like blast, bacterial blight, brown plant hopper and tolerance to abiotic stress have been released in different countries (Lee et al., 1989; Zhu and Pan, 1990; Senadhira et al., 2002; Pauk et al., 2009). The new rice cultivar with multiple disease resistance also required high yield, hence several researchers reported high yielding rice cultivar that can be used for improvement of existing cultivars (Singh et al., 2015; Rashmi et al., 2017). In last decades for rice improvement researchers also worked for yield characteristics (Pratap et al., 2018), molecular characterisation (Tripathy and Dash, 2015) and disease resistance (Kaur et al., 2015). Using conventional breeding methods, plants with multiple resistance genes cannot be selected based on phenotype alone, because of epistasis effect of genes, wherein the action of a gene conferring resistance to many races of the pathogen may mask the action of another resistance gene. Though, using DNA markers it would be possible to select plants having multiple resistance genes without actual disease inoculation if markers linked with resistance genes are available (Kadu et al., 2018). In order to enhance the durability of resistance, molecular markers that are tightly linked to each of these resistance genes have been developed (Zhang, 1996) and used to pyramid them into rice varieties (Singh et al., 2001; Joseph et al., 2004). Among total identified BLB resistance genes most of the genes are dominant in nature while some are recessive. Some of them have been tagged and mapped by closely linked molecular markers (Rao et al., 2002). In Chhattisgarh Dubraj is commonly grown mega rice variety, which is most popular scented rice having tall plant morphology, short to medium grain and high yield. But it is highly susceptible for different biotic stresses like BLB and blast disease. For developing new aromatic rice variety, Dubraj was selected as one of the parent and donors were RPBIO-226 (BLB resistant) and PR 122 (blast resistant). For obtaining aromatic rice with BLB and blast resistance, double crossing was performed and subsequently subjected for anther culture for $\mathrm{DH}$ production.

\section{Materials and Methods}

The Experiments were conducted to screen 7 aromatic rice double haploid (DH) lines (L-1, L-2, L- 3, L- 4, L- 5, L- 6 and L-7) generated from double crossing of Dubraj, RPBIO-226 and
PR122 developed against Bacterial Leaf Bligh (BLB) and blast disease during kharif (June to September) 2018 and 2019 monsoon season. All 7 lines were developed through anther culture in the Department of Plant Molecular Biology and Biotechnology, Indira Gandhi Agriculture University, Raipur, India. In kharif (June to September) 2018 and 2019, 25 days old seedlings of all 7 lines along with positive (RPBIO-226 and PR122) and negative checks (Dubrai), raised in dry seed beds under ideal conditions, were transplanted in a well puddled field with $20 \times 15 \mathrm{~cm}^{2}$ (between and within rows) spacing. Recommended doses of N:P:K (90:60:60) were applied in three split doses. Phenotypic observations were recorded. Ten randomly selected plants from each line evaluated for different traits such as number of panicles plant ${ }^{-1}$, number of tillers plant ${ }^{-1}$, plant height $(\mathrm{cm})$, grain length $(\mathrm{cm})$, grain breadth $(\mathrm{cm})$, L/B ratio, seed weight $(\mathrm{g})$ plant $^{-1}$, aroma and $50 \%$ flowering time. Average of both the years has been taken for all phenotypic observations.

Individual plants of 7 lines along with resistant and susceptible check were also evaluated for field infection to bacterial blight. During experiment, bacterial isolates were collected from Department of Plant Pathology, IGKV, Raipur, Chhatisgarh using modified Wakimoto's Medium with minor modification (Weidenbach et al., 2016). The experimental plant material was inoculated with bacterial isolate at maximum tillering stage following clip inoculation technique (Kauffman et al., 1973) and disease score was evaluated 26 days after inoculation. The lesion length in each plant was measured on five individual leaves and average lesion length was obtained, the further categorization was done based on 0-9 score (Anonymous, 2013). Average of both the years has been taken for all disease resistance score.

The Blast disease was screened under natural environment at Raj Mohini Devi College of Agriculture and Research Station, IGKV, Ambikapur (Chhattisgarh), which is the hotspot for blast disease in Chhattisgarh. The observations of blast infestation were recorded 25-30 days after transplanting. Disease was scored according to standard evaluation system (2013) developed at the International Rice Research Institute, Philippines.

Sensory test for aroma was performed by using a $1.7 \% \mathrm{KOH}$ solution (Sood and Siddiq, 1978). One gram of green leaf blade at the heading stage was cut into small pieces and put into Petri dishes with $5 \mathrm{ml}$ of a $1.7 \% \mathrm{KOH}$ solution at room temperature. After 30 minutes, the dishes were opened and smelled immediately. The presence (+) or absence (-) of aroma was then scored for aroma by a common panel of 4 experts in a scale of 1-4. Score 1 was given for absence of aroma, score 2 was given for slight aroma, score 3 for moderate aroma and score 4 for high aroma. Average of both the years has been taken for aroma scores.

For genotyping of all lines for the presence and absence of disease resistant genes, the genomic DNA was isolated from 
approximately $100 \mathrm{mg}$ of leaf tissue per sample based on the cetyl trimethyl ammonium bromide (CTAB) method (Doyle, 1991). In this research 4 primers viz. xa5R (Panaud et al., 1996), RM13 (McCouch et al., 1997), xa13pro (Singh et al., 2001) and pT248 (Huang et al., 1997) was used to BLB disease screening whereas, primer RM136 (Eizenga et al., 2006), S29742c (Eizenga et al., 2006 ), RM7311a (Cao et al., 2015) and RM1233 (Fjellstrom et al., 2004) was used to screen DH lines against blast disease. Amplification reactions with eight markers were carried out on thermal cycler by preparing $20 \mu \mathrm{l}$ final volume reaction containing $50 \mathrm{ng}$ template DNA and EmeraldAmp GT PCR Master Mix (Takara Bio).This master mix includes an optimized buffer, PCR enzyme ( $2 \mathrm{U}$ $\left.\mu^{-1}\right)$, dNTP mixture (10 mM), gel loading dye (green), and a density reagent in a $2 \mathrm{X}$ premix format. The PCR condition were: denaturation at $94^{\circ} \mathrm{C}$ for 3 minutes, thirty-five cycles of denaturation for $45 \mathrm{sec}$ at $94^{\circ} \mathrm{C}$, annealing for 30 seconds at $50^{\circ} \mathrm{C}$ followed by $30 \mathrm{sec}$ at $72^{\circ} \mathrm{C}$. Final elongation step was at $72^{\circ} \mathrm{C}$ for 10 minutes. The PCR products were stored at $4^{\circ} \mathrm{C}$ before loading. The PCR products were detected using $1.5 \%$ agarose gel electrophoresis along with $100 \mathrm{bp}$ ladder and visualized by ethidium bromide staining under Gel documentation unit (Biorad).

\section{Results and Discussion}

\subsection{Screening for bacterial leaf blight resistance}

$7 \mathrm{DH}$ lines of rice along with resistant (RPBIO-226) and susceptible (Dubraj) controls were screened against the bacterial isolates by using clip inoculation method. Strain of Xoo under epiphytotic conditions during the 2018 and 2019 The strain of $X o O$ is the most aggressive and highly virulent, mostly used to screen Oryza sativa species in India that give diverse responses with the host (Goel et al., 2002). Lesions usually start near the leaf tips or leaf margins or both, and extend down the outer edges. Young lesions are pale green to grayish green, later turning yellow to gray (dead) with time. In very susceptible genotypes, lesions may extend to $>50 \%$ whereas in resistant and moderately resistant genotypes, lesions may extend up to 0 to $5 \%$ and 6 to $12 \%$ respectively (Figure 1). The results of phenotypic screening are presented in Figure 2. On the basis of disease severity at 26 days after inoculation, 3 rice $\mathrm{DH}$ lines showed resistance, 3 were moderately resistance and 1 rice $\mathrm{DH}$ plant were susceptible to strain of Xoo. Similarly, wide responses of genotypes against Xoo were observed earlier by various workers (Ram et al., 2011; Thimmegowda et al., 2011; Sharma and Pandey, 2012). The initial symptoms of BLB, including linear yellow to straw colored stripes with wavy margins, generally on both edges of a leaf and rarely on one edge, were observed with variable intensities. These symptoms first appeared in $\mathrm{DH}$ line (L-2), 8 days after inoculation, while DH lines viz. L-1, L-3, $\mathrm{L}-4, \mathrm{~L}-5, \mathrm{~L}-6$ and $\mathrm{L}-7$ showed these symptoms after 12 days as compared to resistant controls (RPBIO-226), which showed symptoms appears 12 days after inoculation. Susceptible

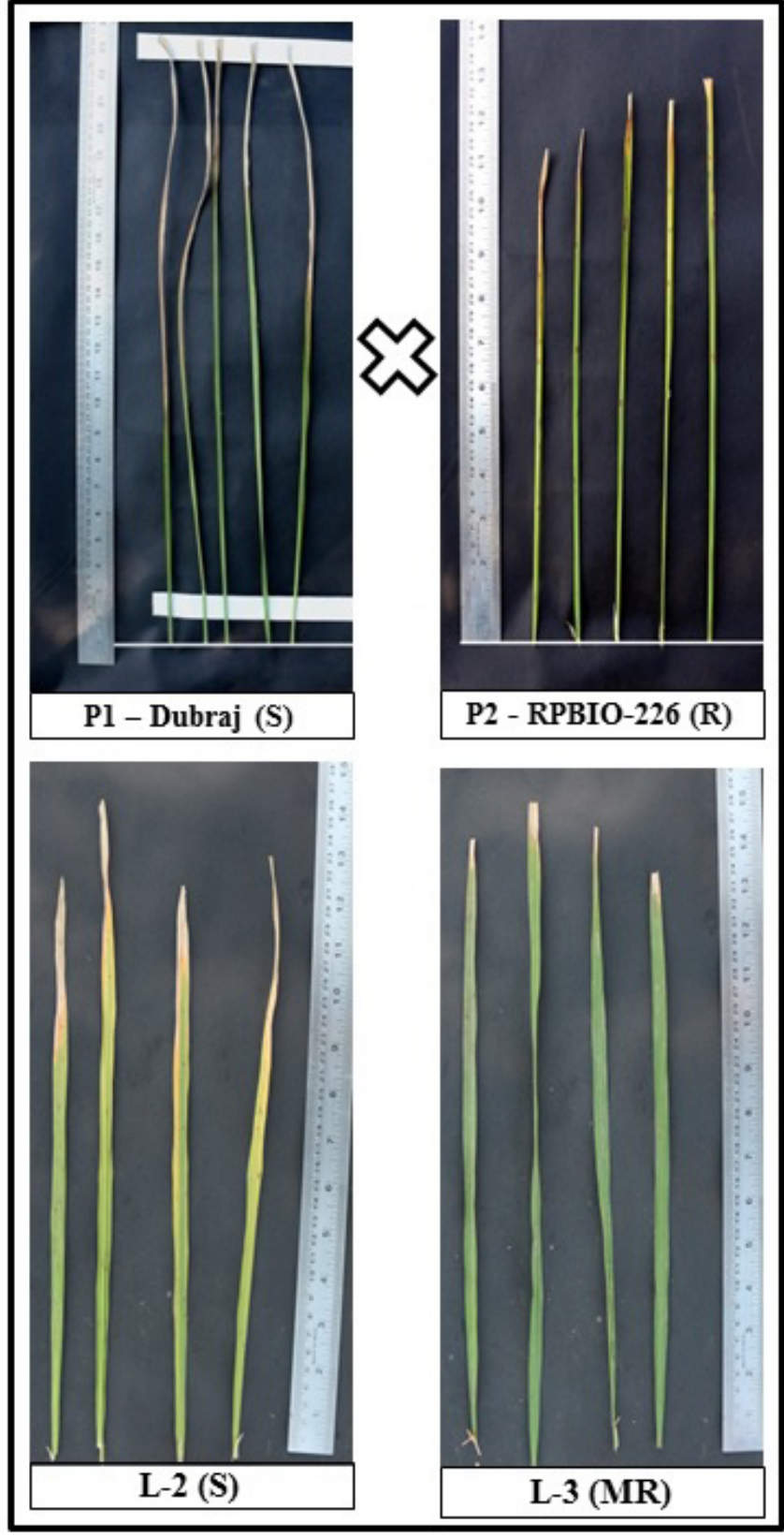

Figure 1: BLB inoculated leaf of RPBIO-226 (Resistant parent) and L-3 (DH line) showing resistance against BLB under field condition along with susceptible genotypes (Dubrajsusceptible parent; L-2- Susceptible DH line)

control Dubraj showed symptoms after 8 days. These findings are in agreement with an earlier report by Singh et al. (2013), who reported that the first symptoms appeared after 7 days in moderately susceptible rice germplasm. Among these $\mathrm{DH}$ lines, L-1, L-6 and L-7 showed the lowest disease score (Score 1) whereas highest disease score (Score 7) was shown by L-2 line. The percentage leaf area diseased ranged from $3.38 \% \%$ (L-1) to $33.51 \% \%(L-2)$ compared with resistant controls RPBIO-226 (4.03\%; Score 1) and susceptible control Dubraj (53.25\%; Score7). The moderately resistant DH lines had 


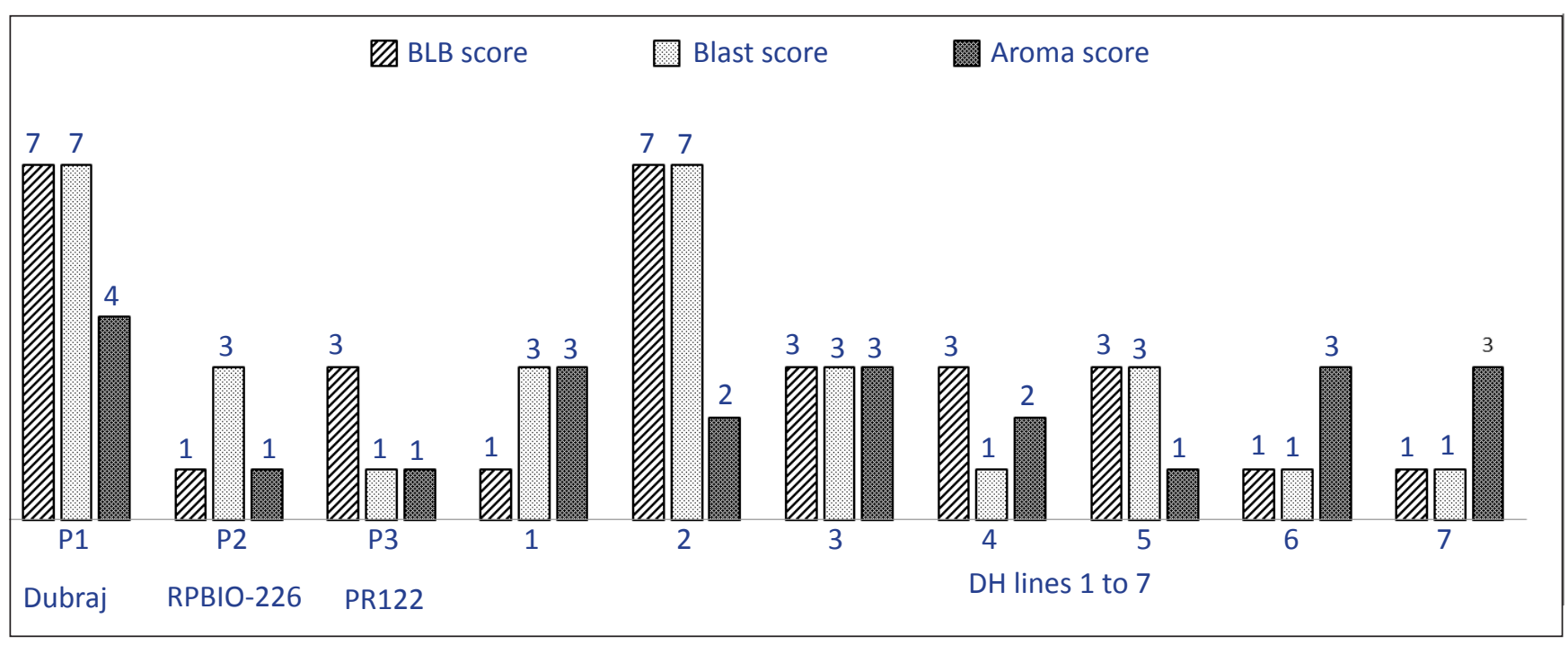

Figure 2: Scoring of BLB and leaf blast using 0-9 standard evaluation scale (Anonymous, 2013) and aroma score by sensory test using a $1.7 \% \mathrm{KOH}$ solution (Avg. of 2018 and 2019)

percentage leaf area diseased values ranging from $8.14 \% \%$ (Score 3 ) to $8.82 \% \%$ (Score 3) and susceptible rice DH L-2 had value of $33.51 \%$ (Score 7 ) presented in Figure 2. The DH lines were classified as resistant, moderately resistant and susceptible. Three $\mathrm{DH}$ lines were resistant to the strain of Xoo and one $\mathrm{DH}$ line was susceptible. Therefore, in the present study, results showed that $\mathrm{DH}$ lines were resistant to BLB disease because of donor variety used in crossing programme (RPBIO-226). These results are in conformity with the earlier findings of Shah et al. (2009).

\subsection{Screening for rice blast resistance}

The blast pathogen affects different parts of a rice plant during pathogenesis. One of the serious forms of rice blast is leaf blast. However, due to very complex nature of M. oryzae, the epidemiology of pathogen is not completely understood. The leaf blast is well studied and the screening method for the same is precisely standardized. Therefore, in the present study the screening carried out for phenotypic evaluation of blast disease resistance. Seven anther culture derived $\mathrm{DH}$ lines of rice along with resistant (PR-122) and susceptible (Dubraj) controls were screened under natural environment at 35 day after transplanting against the fungal pathogen i.e. M. oryzae. Similarly, Yan et al. (2017) also screened set of germplasm for blast disease at 30 days after transplanting and disease reactions were scored ranging according to standard guideline of IRRI. The results show that the $\mathrm{DH}$ lines along with resistant donor had the $P i$ genes were resistant to blast disease. It reveals that these genes recognized the aggression of blast pathogen and continued to initiate a defence mechanism in a system of plants. The recipient parent Dubraj was susceptible to $M$. oryzae races present at Ambikapur district, Chhattisgarh state, India. It indicated that this variety did not have the $P i$ genes that recognized the protein produced by the avr gene. The Donor parent (PR122) for blast disease was resistant to race of $M$. oryzae. It showed that this variety had the Pi genes that recognized the protein produced by the avr gene from the pathogen. Furthermore, the resistance response PR122 variety was compared with the resistance response of the $\mathrm{DH}$ lines that were tested. The check variety Dubraj was confirmed as a susceptible variety supporting the previous report (Shinde et al., 2018). During phenotypic evaluation least scores 1 was recorded by three $\mathrm{DH}$ line corresponded to resistance. Further, three $\mathrm{DH}$ lines were found to be moderately resistance against leaf blast disease with phenotypic scores of 3. The susceptibility with phenotypic score of 7 was recorded by one DH line and susceptible check Dubraj (Figure 2). Based on the scores obtained during the field screening, three $\mathrm{DH}$ lines were classified as resistant (L-4, L-6 and L-7) along with resistant check (PR-122), whereas, another three DH lines were grouped under the section moderately resistant ( $L-1$, L-3 and L- 5) and the remaining $\mathrm{DH}$ line were included in the group susceptible (L-2) (Figure 3). Similar method was followed by researchers for screening of different landraces for blast resistance and observed that some cultivar shows the susceptible reaction against blast (Sowmya et al., 2014; Devi et al., 2015), which is similar with our result. The genetic crossing of the parents showed diverse reactions to blast pathogen. Hence, it can be said that L-1, L-3 and L-5 were moderately resistant to blast pathogen. It indicated that these lines had certain Pi genes that recognized the protein produced by the avr gene from the pathogen and initiated a defense response in the plants. The differential varieties with different Pi genes shows different levels of resistant to blast pathogen. These genes protect plants from the pathogenic attack; however, several genes in different pathotypes groups were susceptible to blast pathogen, including the Pi genes. It indicated that blast pathogen may have the narrowest virulence spectrum in comparison with other races (Hayashi et al., 2009). Similarly researchers reported that the resistance genes from a pathotype group are not always have the same 


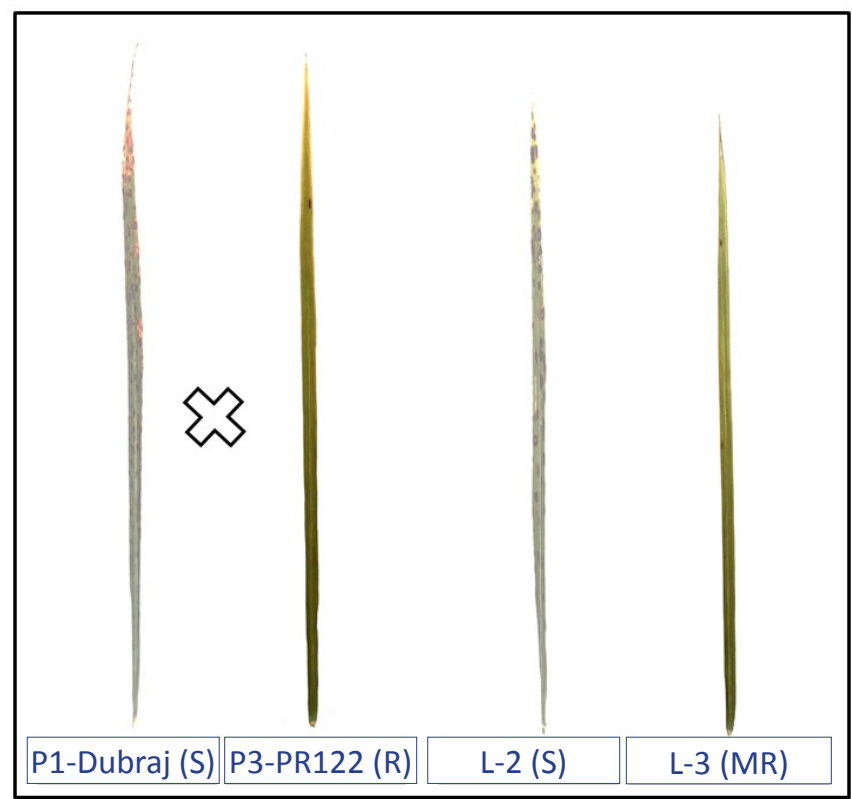

Figure 3: Sample images of rice $\mathrm{DH}$ showing blast resistance phenotypes (L-3) in contrast to susceptible (L-2) along with the resistant (PR122) and susceptible parent (Dubraj)

resistance response to a certain blast race. The differential varieties were used to observe the resistance response to a certain blast race (Hayashi and Fukuta, 2009).

\subsection{Genotyping for bacterial leaf blight resistance}

Same lines were screened for the presence/absence of three BLB resistance genes (Xa21, xa13 and $x a 5)$ using PCR-based markers pT248, xa13pro, RM13 and xa5R. Here, the xa13pro is linked to $x a 13$ gene locus and pT248 linked to genes Xa21 and Reaming markers RM13 and xa5R are associated with xa5 gene. The resistant (RPBIO-226) and susceptible (Dubraj) controls were included as gene differential lines. Estimation of PCR results for the BLB resistance genes were determined by visualization of amplicons near 950 bp (pT248), 530 bp ( xa13pro), $140 \mathrm{bp}$ (RM13) and $160 \mathrm{bp}$ (xa5R) of positive fragments, respectively. The results of genotypic screening of the seven $\mathrm{DH}$ lines are presented in Table 1. Electrophoretic patterns of DNA markers xa13pro, pT248, RM13 and xa5R for $B L B$ resistance genes are shown in the Figure 4. During this polymorphic survey, out of the seven $\mathrm{DH}$ lines, only three $\mathrm{DH}$ lines had amplicons specific to xa13 alleles, showing the presence of these gene in $\mathrm{DH}$ lines evaluated along with resistant control RPBIO-226. Four DH lines amplified $160 \mathrm{bp}$ fragments (xa5R) and five DH lines amplified $140 \mathrm{bp}$ fragments (RM13) along with RPBIO- 226 indicating the presence of xa5 gene. Two DH lines along with resistant parent (RPBIO226) amplified $950 \mathrm{bp}$ fragments, indicating the presence of $X a 21$ gene. In the present study, $\mathrm{DH}$ lines with the presence of three BLB resistance genes, Xa21, xa13 and $x a 5$ were identified, which were reported to give broad-spectrum resistance to different races of Xoo. The gene $X a 21$ and $x a 13$
Table 1: PCR Amplification of seven DH lines for xa5, xa13, and Xa21 gene locus for BLB Resistance

\begin{tabular}{lccccc}
\hline \multirow{2}{*}{ SI. } & Line name & \multicolumn{2}{c}{ xa5 } & xa13 & Xa21 \\
\cline { 3 - 6 } & & \multicolumn{2}{c}{ Markers } & Marker & Marker \\
\cline { 3 - 6 } & & Xa5R & RM13 & Xa13pro & PT248 \\
\hline P1 & DUBRAJ & $\times$ & $\times$ & $\times$ & $\times$ \\
P2 & RPBIO-226 & Xa5R & RM13 & Xa13pro & PT248 \\
1 & L-1 & Xa5R & $\times$ & Xa13pro & $\times$ \\
2 & L-2 & $\times$ & RM13 & $\times$ & $\times$ \\
3 & L-3 & Xa5R & $\times$ & Xa13pro & $\times$ \\
4 & L-4 & $\times$ & RM13 & $\times$ & $\times$ \\
5 & L-5 & $\times$ & RM13 & $\times$ & $\times$ \\
6 & L-6 & Xa5R & RM13 & Xa13pro & PT248 \\
7 & L-7 & Xa5R & RM13 & $\times$ & PT248 \\
\hline
\end{tabular}

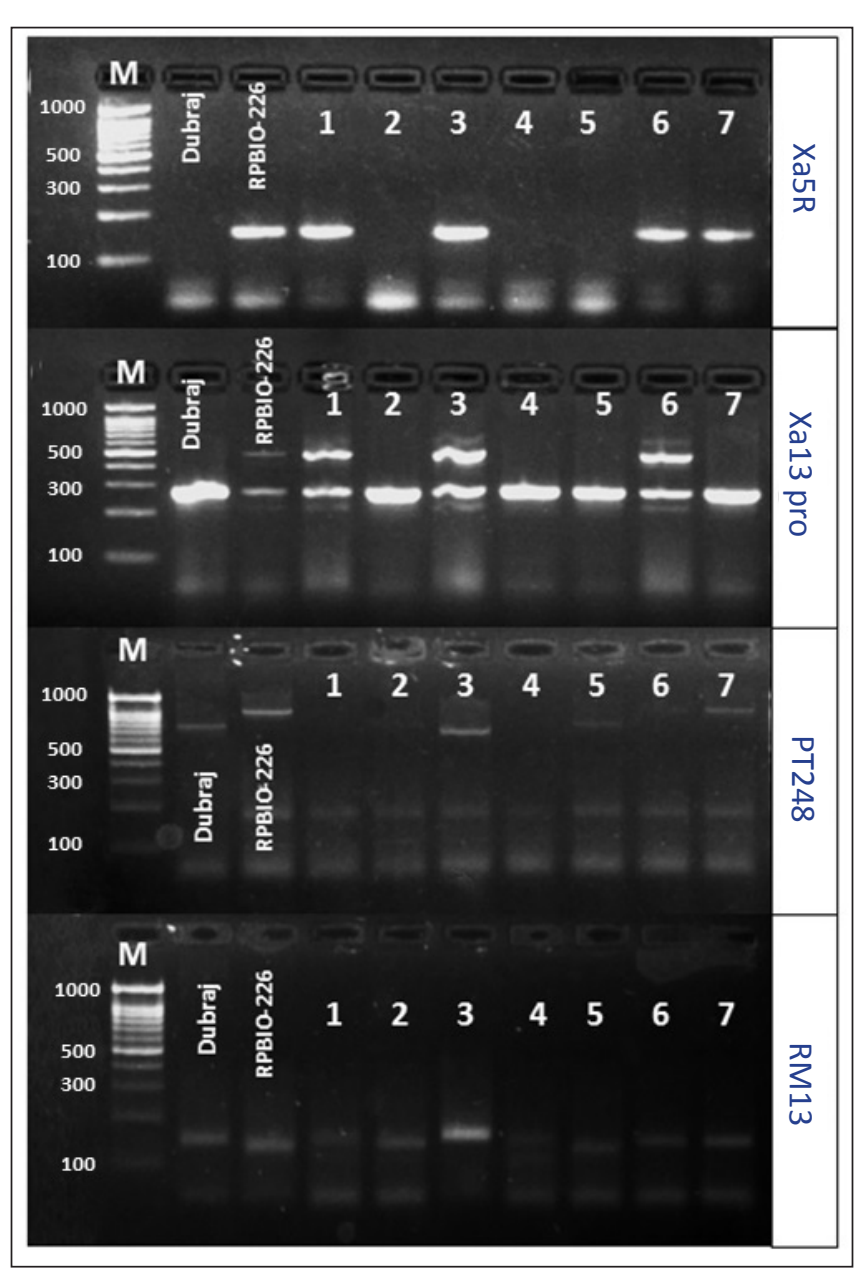

Figure 4: Agarose gel electrophoretic pattern of rice $\mathrm{DH}$ lines generated by using xa5R, xa13pro, pT248 and RM13 markers linked to BLB resistance genes, where $M$ is $100-b p$ DNA size marker, RPBIO-226 is BLB resistant variety, Dubraj is BLB susceptible variety and numbers $1-7$ represent $\mathrm{DH}$ lines 
were identified in two ( $L-6$ and $L-7$ ), and three (L-1, L-3 and $\mathrm{L}-6) \mathrm{DH}$ lines respectively. The gene $x a 5$ was found in all $\mathrm{DH}$ lines, wherein gene combinations such as $X a 21, x a 13$ and $x a 5$ were also found in L- 6 line along with resistant parent PR-122. The combination of $x a 13$ and $x a 5$ gens was found in three $\mathrm{DH}$ lines, viz L-1, L-3 and L-6. The present findings are in agreement with the reports of Davierwala et al. (2001), who surveyed rice genotypes popularly used in Indian breeding programs using markers closely linked to xa5, xa13 and Xa21 genes. They reported that 8 lines carried $x a 5$, four had $x a 13$ and only 2 of them carried Xa21. The resistance gene $x a 5$ has been positionally cloned and encodes the gamma subunit of transcription factor IIA. Sequencing of transcription factor IIA in resistant and susceptible isolines revealed two nucleotide substitutions resulting in an amino acid change between resistant and susceptible cultivars. The identification and characterization of major genes for qualitative resistance and polygenic factors controlling quantitative resistance have contributed a great deal to success in breeding resistant cultivars. Many of these identified genes have been incorporated into modern rice varieties and exhibited complete resistance against the pathogens (Sanchez et al., 2000). Among the wild rice accessions, $25.71 \%$ possessed the $x a 5$ gene. The $x a 5$ gene alone was not effective against many of the Xoo pathotypes evaluated from Punjab (Lore et al., 2011) and the broad-spectrum resistance observed here may be due to the presence of one or more additional genes or modifiers in most of the $\mathrm{DH}$ lines. The xa5 gene is one of the most widely exploited resistance genes in many Asian rice breeding programs and it conferred durable resistance in many commercial rice cultivars (Mew et al., 1992). The pyramided lines with $x a 13$ and other resistance genes showed a wider spectrum and a higher level of resistance than the lines with a single resistance gene (Huang et al., 1997). This calls for further detailed genetic analysis of the presence of novel BLB resistance genes and their tagging and cloning in wild rice accessions. This information can be gainfully utilized to supplement the BLB resistant gene pool available in India. The selected DNA markers for respective genes were highly reliable and make them the markers of choice for molecular screening of BLB-resistant genes among the rice $\mathrm{DH}$ lines. The presence of $\mathrm{Xa21}$ xa13 and $x a 5$ genes in $\mathrm{DH}$ lines is lacking in modern cultivars. Hence, the $\mathrm{DH}$ line can be use as modern cultivars, which is developed for BLB-resistant through pyramiding and $\mathrm{DH}$ approaches without compromising yield and grain quality.

\subsection{Genotyping for blast disease}

The resistance response to blast pathogen is controlled by the resistance gene in the host. The presence of this resistance gene can be identified using molecular markers. In this research, four primers were used to amplify the targeted DNA fragments as the markers for the Pi1 and Pi2 genes on all DH lines tested. The PCR results show three primers could amplify the targeted DNA fragments (RM1233, S29742c and
RM7311a), while one primer could not amplify the targeted DNA fragments (RM136). Therefore, the three primers were used to amplify the targeted DNA fragments on DH lines. Part of the PCR product profiles tested which contained: parents (PR-122- resistant; Dubraj- susceptible) and DH lines were shown in Figure 5, while the PCR scoring of the PCR product total was shown on Table 2. Estimation of PCR results for the blast resistance genes were determined by visualization of amplicons near 160bp (RM1233), 570bp (S29742c) and 150bp (RM7311a) of positive fragments. The electrophoretic patterns of DNA markers RM1233 representing resistance genes Pi1, whereas marker S29742c, RM136 and RM7311a for Pi2 resistance genes are shown in the Table 2 . After the PCR analysis polymorphic marker evaluation shown, out of the seven DH lines, six DH lines had amplicons specific to Pi1 alleles (RM1233-160 bp), showing the presence of these gene in $\mathrm{DH}$ lines evaluated along with resistant control PR-122. All DH lines amplified 570 bp fragments of S29742c marker and four DH lines amplified $150 \mathrm{bp}$ fragments of RM7311a marker along with PR-122 indicating the presence of Pi2 gene. This study aimed at development of advanced $\mathrm{DH}$ carrying genes for blast resistant by using donor PR-122, which is the rice

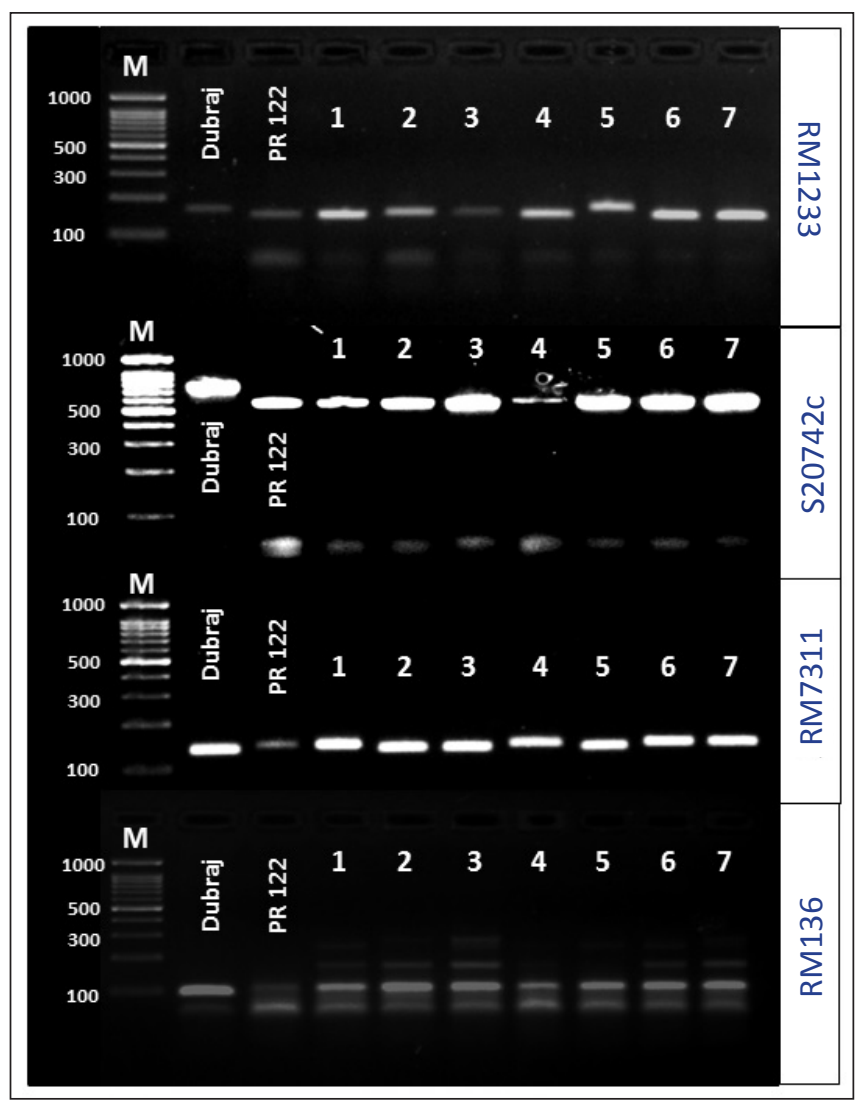

Figure 5: Agarose gel electrophoretic pattern of rice $\mathrm{DH}$ lines generated by using RM1233, S29742c, RM7311a and RM136 markers linked to Blast resistance genes, where $M$ is $100-b p$ DNA size marker, PR122 is blast resistant variety, Dubraj is blast susceptible variety and numbers $1-7$ represent $D H$ lines 
Table 2: PCR Amplification of seven DH lines for Pi1 and Pi2 gene locus for blast resistance

\begin{tabular}{|c|c|c|c|c|c|}
\hline \multirow{4}{*}{$\begin{array}{l}\text { Sl. } \\
\text { No. }\end{array}$} & \multirow{4}{*}{$\begin{array}{l}\text { Line } \\
\text { name }\end{array}$} & \multicolumn{4}{|c|}{ Blast disease resistance genes } \\
\hline & & \multirow{2}{*}{$\begin{array}{c}\text { Pi1 } \\
\text { Markers }\end{array}$} & \multicolumn{3}{|c|}{ Pi2 } \\
\hline & & & & Markers & \\
\hline & & RM1233 & S29742c & RM7311a & RM136 \\
\hline P1 & Dubraj & $x$ & $x$ & $x$ & $x$ \\
\hline P3 & PR122 & RM1233 & S29742c & RM7311a & RM136 \\
\hline 1 & $\mathrm{~L}-1$ & RM1233 & S29742c & RM7311a & $x$ \\
\hline 2 & $L-2$ & RM1233 & S29742c & $x$ & $x$ \\
\hline 3 & $L-3$ & RM1233 & S29742c & $x$ & $x$ \\
\hline 4 & $L-4$ & RM1233 & S29742c & RM7311a & $x$ \\
\hline 5 & $L-5$ & $x$ & S29742c & $x$ & $x$ \\
\hline 6 & $L-6$ & RM1233 & S29742c & RM7311a & $x$ \\
\hline 7 & $L-7$ & RM1233 & S29742c & RM7311a & $x$ \\
\hline
\end{tabular}

variety of Punjab carry unique resistant genes (Rekha et al., 2011), that lower the risk of disease attack, compared to the high yielding varieties (Devi et al., 2017). In the present study, DH lines with the presence of two blast resistance genes, Pi1 and $P$ i2 were identified, which were reported to give broadspectrum resistance to different races of Magnaporthe oryzae (Liu et al., 2002; Khan et al., 2018). The gene Pi1 was found in six DH lines (L-1, L-2, L-3, L-4, L-6 and L-7) and the gene Pi2 was found in all seven $\mathrm{DH}$ lines, wherein gene combinations such as Pi1 and Pi2 were also found in six DH lines ( $L-1, \mathrm{~L}-2$, L-3, L-4, L-6 and L-7) along with resistant parent PR-122. The comparison of disease scores with the presence or absence of resistance genes clearly showed that the $\mathrm{DH}$ lines having genes Pi1 and Pi2 had lower disease score supporting the previous findings about these genes in delivering broad-spectrum resistance against geographically diverse strains of $M$. oryzae (Kumari et al., 2017; Khan et al., 2018). This emphasizes that the pyramiding of genes Pi1 and Pi2 can undoubtedly impart better blast resistance under Chhattisgarh conditions.

\subsection{Aroma estimation by using sensory test}

The presence or absence of aroma in the rice leaf tissues was assessed on same $7 \mathrm{DH}$ rice lines including positive and negative check (Dubraj- Aromatic positive check; RPBIO226 and PR122-Non-aromatic negative check) identified by the sensory test using a $1.7 \% \mathrm{KOH}$ solution. On the basis of sensory test results the $\mathrm{DH}$ lines along with parents assigned to score 1 for absence of aroma, score 2 for slight aroma, score 3 for moderate aroma and score 4 for high aroma (Figure 2). The smell was neutralized using coffee powder in between estimating lines. The results indicated the existence of a moderately strong aroma present in four DH lines (L-1, L-3, $\mathrm{L}-6$ and $\mathrm{L}-7$ ) except for three lines (L-2, L-4 and L-5). All though there was a considerable variation among the $\mathrm{DH}$ lines in the aroma level. The focused was on the presence or absence of aroma in 1-4 scale levels .No quantitative determination was performed. Moreover, sensory assessment of aroma in rice is still favourable method applied in some studies (Lorieux et al., 1996; Garland et al., 2000). So the test performed was sufficient to discriminate different levels of aroma in comparison to positive and negative checks.

\subsection{Morphological characterization of $D H$ lines}

$7 \mathrm{DH}$ lines derived along with parents were field evaluated for different agronomic traits: number of panicles plant ${ }^{-1}$, number of tillers plant ${ }^{-1}$, plant height $(\mathrm{cm})$, grain length $(\mathrm{cm})$, grain breadth $(\mathrm{cm})$, L/B ratio, seed weight $(\mathrm{g})$ plant $^{-1}$, aroma and $50 \%$ flowering time (Figure 6). All traits showed a wide variation among the anther derived rice lines. For maturity, none of the $\mathrm{DH}$ lines exhibited longer duration and for plant

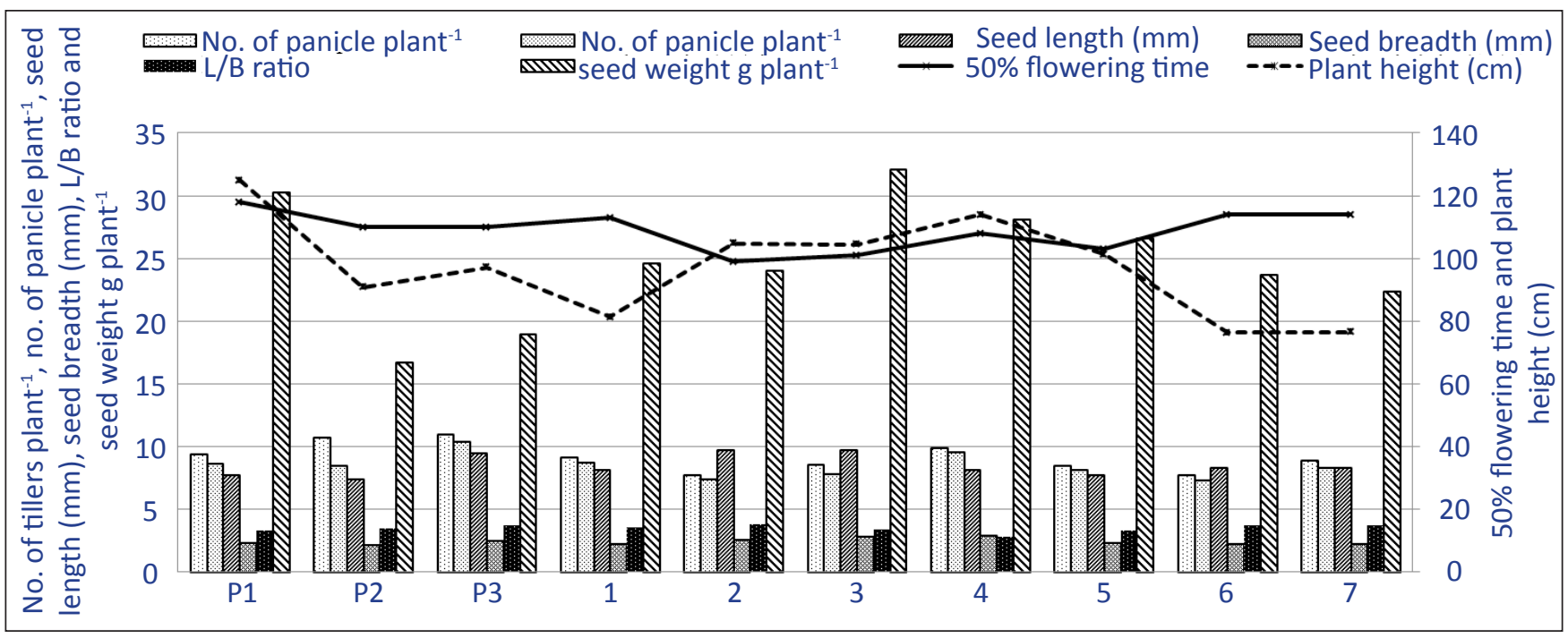

Figure 6: Morphological characterization of DH lines (Avg. of 2018 and 2019) where, P1 is Dubraj, P2 is RPBIO-226, P3 is PR122 and numbers $1-7$ represent $\mathrm{DH}$ lines 
height all DH lines were shorter than the Dubraj. The L/B ratio derived from grain length and grain breadth was higher in six DH lines (L-1, L-2, L-3, L-5, L- 6 and L-7) whereas lower in one DH line (L-4) as compared to recipient donor. The values of different traits were well distributed among all $\mathrm{DH}$ lines. Among all the screened lines, aromatic L-3 DH line performed outstandingly well with higher seed weight (32.11 g plant $^{-1}$ ) higher than Dubraj (30.20 g plant $^{-1}$ ) and moderate resistance to BLB and blast. Subsequently L-3 line was subjected to SIET trial showing excellent yield performance ( $5096.5 \mathrm{~kg} \mathrm{ha}^{-1}$ ) as compare to several local checks (swarna $4791.7 \mathrm{~kg} \mathrm{ha}^{-1}$; Mashuri $4148.1 \mathrm{~kg} \mathrm{ha}^{-1}$; Pooja $4398.1 \mathrm{~kg} \mathrm{ha}^{-1}$, Jaldubi $2507.7 \mathrm{~kg} \mathrm{ha}^{-1}$ ). Yield of $51 \mathrm{q} \mathrm{ha}^{-1}$ is appreciable as most of the aromatic lines yields between 3.5-4.5 q ha-1. Underlying objective of this research was to develop DH lines and select the high yielding aromatic rice line with multiple disease resistant. Within 3 years of development of L-3 DH, it is under varietal developmental trails, which itself indicate the efficacy of anther culture in fixing homozygosity and speedy development of desired variety within short period of time. L-3 is promoted to advance evaluation trials and iss nominated for IVT trial under AICRIP for checking its national performance.

\section{Conclusion}

DNA markers, pathogenicity assays and sensory test was judicially employed to confirm the morphological data. DH line L-3 came out to be the best performer and it is under advanced trial due to its superior qualities and expected to be released as aromatic $\mathrm{DH}$ line with multiple disease resistance in years to come.

\section{Future Research}

The selected resistant DH lines may further be used in crossing program to introduce other resistant genes of different biotic and abiotic stresses.

\section{References}

Babujee, L., Gnanamanickam, S.S., 2000. Molecular tools for characterization of rice blast pathogen (Magnaporthe grisea) population and molecular marker-assisted breeding for disease resistance. Current Science Bangalore 78(3), 248-257.

Cao, Z., Zeng, G., Hao, M., Sheng, H.W., Ye, N.Z., Xiao, Y.H., 2015. Improving blast resistance of dual-purpose genic sterile line C815S by using molecular marker-assisted selection. Molecular Plant Breeding 13(6), 1193-1200.

Chen, M., Presting, G., Barbazuk, W.B., Goicoechea, J.L., Blackmon, B., Fang, G., Kim, H., Frisch, D., Yu, Y., Sun, S., Higingbottom, S., 2002. An integrated physical and genetic map of the rice genome. The Plant Cell 14(3), 537-545.

Chukwu, S.C., Rafii, M.Y., Ramlee, S.I., Ismail, S.I., Hasan, M.M., Oladosu, Y.A., Magaji, U.G., Akos, I., Olalekan,
K.K., 2019. Bacterial leaf blight resistance in rice: a review of conventional breeding to molecular approach. Molecular Biology Reports 46(1), 1519-1532. Davierwala, A.P., Reddy, A.P.K., Lagu, M.D., Ranjekar, P.K., Gupta, V.S., 2001. Marker assisted selection of bacterial blight resistance genes in rice. Biochemical Genetics 39(7), 261-278.

Devi, P.I., Solomon, S.S., Narayanan, M., 2017. Conservation of traditional rice varieties for crop diversity in Kerala. ANGRAU, 93.

Devi, S.R., Singh, K., Umakanth, B., Vishalakshi, B., Renuka, P., Sudhakar, K.V., Prasad, M.S., Viraktamath, B.C., Babu, V.R., Madhav, M.S., 2015. Development and identification of novel rice blast resistant sources and their characterization using molecular markers. Rice Science 22(6), 300-308.

Doyle, J., 1991. DNA protocols for plants. In: Molecular techniques in taxonomy. Springer, Berlin, Heidelberg 283-293.

Eizenga, G.C., Agrama, H.A., Lee, F.N., Yan, W., Jia, Y., 2006. Identifying novel resistance genes in newly introduced blast resistant rice germplasm. Crop Science 46(5), 1870-1878.

Fjellstrom, R., Conaway-Bormans, C.A., McClung, A.M., Marchetti, M.A., Shank, A.R., Park, W.D., 2004. Development of DNA markers suitable for marker assisted selection of three Pi genes conferring resistance to multiple Pyricularia grisea pathotypes. Crop Science 44(5), 1790-1798.

Garland, S., Lewin, L., Blakeney, A., Reinke, R., Henry, R., 2000. PCR-based molecular markers for the fragrance gene in rice (Oryza sativa. L.). Theoretical and Applied Genetics 101(3), 364-371.

Goel, A.K., Rajagopal, L., Nagesh, N., Sonti, R.V., 2002. Genetic locus encoding functions involved in biosynthesis and outer membrane localization of xanthomonadin in Xanthomonas oryzae pv. oryzae. Journal of Bacteriology 184(13), 3539-3548.

Hayashi, N., Fukuta, Y., 2009. Proposal for a new international system of differentiating races of blast (Pyricularia oryzae Cavara) by using LTH monogenic lines in rice (Oryza sativa L.). JIRCAS Working report 63, 11-15.

Hayashi, N., Kobayashi, N., Cruz, C., Fukuta, Y., 2009. Protocols for the sampling of diseased specimens and evaluation of blast disease in rice. JIRCAS Working Report 63, 17-33.

Huang, N., Angeles, E.R., Domingo, J., Magpantay, G., Singh, S., Zhang, G., Kumaravadivel, N., Bennett, J., Khush, G.S., 1997. Pyramiding of bacterial blight resistance genes in rice: marker-assisted selection using RFLP and PCR. Theoretical and Applied Genetics, 95(3), 313-320. election into indica rice cultivar PR106. Theoretical and Applied Genetics 102(6), 1011-1015.

Joseph, M., Gopalakrishnan, S., Sharma, R.K., Singhm, V.P., Singhm, A.K., Singhm, N.K., Mohapatra, T., 2004. Combining bacterial blight resistance and Basmati 
quality characteristics by phenotypic and molecular marker assisted selection in rice. Molecular Breeding 13, 377-387.

Kadu, T.P., Kale, S.S., Chavan, N.R., Agrawal, T., Verulkar, S.B., 2018. Pyramiding of three bacterial blight resistance genes in rice cultivar using marker assisted selection. International Journal of Bio-resource and Stress Management 9(2), 243-248.

Kauffman, H. E., Reddy, A. P. K., Heish, S. P. V., Marca, S. D., 1973. An improved technique for evaluating resistance of rice varieties to Xanthomonas oryzae. Plant Disease Report 57, 537-541.

Kaur, A., Dhaliwal, L.K., Pannu, P.P.S., 2015. Role of Meteorological Parameters on Sheath Blight of Rice under different Planting Methods. International Journal of Bio-Resource \& Stress Management 6(2), 214-219.

Khan, G.H., Shikari, A.B., Vaishnavi, R., Najeeb, S., Padder, B.A., Bhat, Z.A., Parray, G.A., Bhat, M.A., Kumar, R., Singh, N.K., 2018. Marker-assisted introgression of three dominant blast resistance genes into an aromatic rice cultivar Mushk Budji. Scientific Reports 8(1), 1-13.

Kumari, M., Devanna, B.N., Singh, P.K., Rajashekara, H., Sharma, V., Sharma, T.R., 2018. Stacking of blast resistance orthologue genes in susceptible indica rice line improves resistance against Magnaporthe oryzae. 3 Biotechnology 8(1), 37.

Lee, Y.T., Lim, M.S., Kim, H.S., Shin, H.T., Kim, C.H., Bae, S.H., Cho, C.I., 1989. An anther-derived new high quality rice variety with disease and insect resistance" Hwacheongbyeo". Research Reports of the Rural Development Administration, Rice 31(2), 27-34.

Liu, G., Lu, G., Zeng, L., Wang, G.L., 2002. Two broad-spectrum blast resistance genes, $\mathrm{Pi} 9(\mathrm{t})$ and $\mathrm{Pi} 2(\mathrm{t})$, are physically linked on rice chromosome 6 . Molecular Genetics and Genomics 267(4), 472-480.

Lore, J.S., Vikal, Y., Hunjan, M.S., Goel, R.K., Bharaj, T.S., Raina, G.L., 2011. Genotypic and pathotypic diversity of Xanthomonas oryzae pv. oryzae, the cause of bacterial blight of rice in Punjab State of India. Journal of Phytopathology 159(7-8), 479-487.

Lorieux, M., Petrov, M., Huang, N., Guiderdoni, E., Ghesquière, A., 1996. Aroma in rice: genetic analysis of a quantitative trait. Theoretical and Applied Genetics 93(7), 1145-1151.

Marassi, M.A., Scocchi, A., Gonzalez, A.M., 2006. Plant regeneration from rice anthers cryopreserved by an encapsulation/dehydration technique. In Vitro Cellular \& Developmental Biology-Plant 42(1), 31-36.

McCouch, S.R., 1997. Report on QTL nomenclature. Rice Genetics Newsletter 14, 11-13.

Mew, T.W., Vera Cruz, C.M., Medalla, E.S., 1992. Changes in race frequency of Xanthomonas oryzae pv. oryzae in response to rice cultivars planted in the Philippines. Plant Disease 76(10), 1029-1032.

Mew,T.W., 1992. Bacterial blight compendium of rice diseases. Robert, K.W., Pamela, S.G. (Eds.). St.Paul: American Phytopathological Society 10-11.

Ou, S.H., 1985. Rice diseases. International Rice Research Institute (IRRI) report, Philippines

Panaud, O., Chen, X., McCouch, S.R., 1996. Development of microsatellite markers and characterization of simple sequence length polymorphism (SSLP) in rice (Oryza sativa L.). Molecular and General Genetics 252(5), 597-607.

Pauk, J., Jancso, M., Simon-Kiss, I., 2009. Rice doubled haploids and breeding. In Advances in haploid production in higher plants. Springer, Dordrecht, 189-197.

Pratap, A., Bisen, P., Loitongbam, B., Singh, P.K., 2018. Assessment of genetic variability for yield and yield components in rice (Oryza sativa L.) germplasms. International Journal of Bio-resource and Stress Management 9(1), 87-92.

Ram, T., Laha, G.S., Deen, R., Ramos, J.M., VeraCruz, C.M., Brar, D.S., 2011. Oryza rufipogon, a valuable source for resistance to bacterial blight of rice. Plant Breeding, 130(6), 715-718.

Rao, K.K., Lakshminarasu, M., Jena, K.K., 2002. DNA markers and marker-assisted breeding for durable resistance to bacterial blight disease in rice. Biotechnology Advances 20, 33-47.

Rashmi, D., Saha, S., Loitongbam, B., Singh, S., Singh, P.K., 2017. Genetic variability study for yield and yield components in rice (Oryza sativa L.). International Journal of Agriculture, Environment and Biotechnology 10(2), 171-176.

Rekha, T., Martin, K.P., Sreekumar, V.B., Madassery, J., 2011. Genetic diversity assessment of rarely cultivated traditional indica rice (Oryza sativa L.) varieties. Biotechnology Research International 2011(1) 1-7.

Sanchez, A.C., Brar, D.S., Huang, N., Li, Z., Khush, G.S., 2000. Sequence tagged site marker-assisted selection for three bacterial blight resistance genes in rice. Crop Science 40(3), 792-797.

Senadhira, D., Zapata-Arias, F.J., Gregorio, G.B., Alejar, M.S., De La Cruz, H.C., Padolina, T.F., Galvez, A.M., 2002. Development of the first salt-tolerant rice cultivar through indica/indica anther culture. Field Crops Research 76(3), 103-110.

Shah, S.M.A., Rahman, H., Abassi, F.M., Akhtar, M.A., Rafi, A., Khan, I.A., 2009. Resistance characterization of wild relatives of rice in response to bacterial blight. Pakistan Journal of Botany 41(2), 917-925.

Sharma, B., Pandey, M.P., 2012. Identification of rice germplasm with resistance to bacterial leaf blight (Xanthomonas oryzae pv. oryzae). Bangladesh Journal of Agricultural Research 37(2), 349-353.

Shinde, U.D., Toshy, A.A., Kadu, T., Kotasthane, A.S., Verulkar, S.B., 2018. Development of blast resistant dubraj by introgression of resistant genes through marker assisted 
selection. International Journal Current Microbiology and Applied Science 7(6), 3113-3118.

Singh, A.K., Sarma, B.K., Singh, P.K., Nandan, R., 2013. Screening of rice (Oryza sativa L.) germplasms against Xanthomonas oryzae pv. oryzae. Journal of Eco-friendly Agriculture 8(1), 86-88.

Singh, A.K., Singh, R.K., Kumar, S., Arya, M., Singh, P.K., 2015 a. Genetic variability to improve yield and resistance to bacterial leaf blight in rice. Bangladesh Journal of Botany 44(4), 581-589.

Singh, S., Sidhu, J.S., Huang, N., Vikal, Y., Li, Z., Brar, D.S., Dhaliwal, H.S., Khush, G.S., 2001. Pyramiding three bacterial blight resistance genes (xa5, xa13 and Xa21) using marker-assisted selection into indica rice cultivar PR106. Theoretical and Applied Genetics 102(6), 1011-1015.

Singh, S., Sidhu, J.S., Huang, N., Vikal, Y., Li, Z., Brar, D.S., Dhaliwal, H.S., Khush, G.S., 2001. Pyramiding three bacterial blight resistance genes (xa5, xa13 and Xa21) using marker-assisted selection into indica rice cultivar PR106. Theoretical and Applied Genetics 102, 10111015.

Sood, B.C., Siddiq, E.A., 1978. A rapid technique for scent determination in rice. Indian Journal of Genetics and Plant Breeding 38(2), 268-275.

Sowmya, H.M., Prashanthi, S.K., Hegde, Y.R., 2014. Traditional landraces of rice for blast (Magnaporthe oryzae) resistance and analysis of biochemical components involved in disease reaction. Asian Journal of Bioscience
9(2), 261-266.

Thimmegowda, P.R., Ambika, D.S., Manjunatha, A.R., Sataraddi, P.P., Chandrashekar, M., 2011. Screening germplasm for resistance to bacterial blight of rice caused by Xanthomonas oryzae pv. oryzae. International Journal of Science and Nature 2(3), 659-661.

Tripathy, S.K., Dash, S., 2015. Genotyping of drought tolerant upland land races of rice using SDS-PAGE of total seed storage protein. International Journal of Bio-resource and Stress Management 6(3), 322-329.

Yan, L., Bai-Yuan, Y., Yun-Liang, P., Zhi-Juan, J., Yu-Xiang, Z., Han-Lin, W., Chang-Deng, Y., 2017. Molecular screening of blast resistance genes in rice germplasms resistant to Magnaporthe oryzae. Rice Science 24(1), 41-47.

Yasmin, S., Hafeez, F.Y., Mirza, M.S., Rasul, M., Arshad, H.M., Zubair, M., Iqbal, M., 2017. Biocontrol of bacterial leaf blight of rice and profiling of secondary metabolites produced by rhizospheric Pseudomonas aeruginosa BRp3. Frontiers in Microbiology 8, 1895.

Zhang, G., Angeles, E.R., Abenes, M.L.P., Khush, G.S., Huang, N., 1996. RAPD and RFLP mapping of the bacterial blight resistance gene xa13in rice. Theoretical and Applied Genetics 93(1-2), 65-70.

Zhu, D., Pan, X., 1990. Rice (Oryza sativa L.): Guan 18-an improved variety through anther culture. In Haploids in Crop Improvement I. Springer, Berlin, Heidelberg 204-211. 